УДК 159.944.4:159.9.019.4-055.52

DOI https://doi.org/10.32838/2709-3093/2021.3/25

Чернякова Г.А.

Сумський державний університет

\title{
ВЗАСМОЗВ'ЯЗКИ КОПІНГ-СТРАТЕГІЙ БАТЬКІВ З ІНДИВІДУАЛЬНО-ПСИХОЛОГІЧНИМИ ВЛАСТИВОСТЯМИ ОСОБИСТОСТІ ПІДЛІТКІВ
}

У статті розкрито поняття «копінг-поведінка» особистості як когнітивні, емоційні та поведінкові зусилля для подолання стресових ситуачій. Розглянуто проблему взаємозв'язку батьківських копінг-стратегій з індивідуально-психологічними властивостями особистості підлітків. Представлено короткий аналіз результатів дослідження індивідуальних способів подолання батьками стресових ситуацій, пов'язаних із вихованням, і таких індивідуальнопсихологічних особливостей підлітків, як: рівень тривожності, самооиінки й агресії. Акиентовано увагу на значному впливі середовища, щзо підтримує, сім'ї на розвиток особистості підлітка у кризові періоди як індивідуального розвитку, так і суспільства загалом.

Представлено аналіз останніх зарубіжних і вітчизняних досліджень і публікаиій щьодо проблеми копінг-поведінки особистості у стресових ситуачіях, а також проблеми батьківськодитячих взаємин у період підліткової кризи. Розглянуто основні підходи до вивчення проблеми копінгу: его-орієнтований, диспозиційний, динамічний. Розкрито поняття копінг-стратегій, представлено їх класифікацію.

Встановлено, що використання батьками ефективних когнітивних, емоиійних та поведінкових копінг-стратегій у подоланні складних ситуачій, пов 'язаних із вихованням, впливає на такі індивідуально-психологічні властивості особистості підлітків, як показники агресивності, рівень самооиінки та тривожності, у бік їхньої оптимізаиії. У сім'ях, де батьки у подоланні труднощів проявляють неадаптивні копінг-стратегії, підлітки мають високий рівень агресії, занижену чи завищену (неадекватну) самооцінку та високий рівень тривожності.

Ефективна копінг-поведінка батьків сприяє гармонійному розвитку особистості підлітка, а формування ефективних копінг-стратегій батьків є пріоритетним завданням для практичних та теоретичних досліджень у галузі сучасної психологічної науки.

Ключові слова: копінг-поведінка, когнітивні, емочійні, поведінкові копінг-стратегї, ефективність копінгу, стрес, тривожність, агресія, самооиінка, підлітковий вік.

Постановка проблеми. Сучасне українське суспільство переживає гострі потрясіння: економічна та політична нестабільність, пандемії та карантинні обмеження, гібридні війни та низка інших кризових процесів, які проявляються на рівні макро- та мікросоціуму, впливають на психологічний стан кожної окремої особистості.

Особливо цінним у кризові періоди розвитку як конкретної особистості, так і суспільства загалом, стає середовище сім'ї, що підтримує. Сімейна ж дисгармонія може стати потужним джерелом психологічної травматизації людини, вносити дисбаланс у психічний розвиток особистості на різних етапах іiі життя.

Підлітковий вік $є$ одним із найважливіших та найсуперечливіших етапів у житті людини, особливості його перебігу зумовлюють психофізіологічні, репродуктивні, інтелектуальні, адаптивні можливості особистості упродовж усього майбутнього життя людини, і це саме той період, коли вона гостро потребує батьківської підтримки та виваженої виховної позиції.

У сім'ї, де виховується підліток, перед батьками постійно постають складні ситуації, які потребують адекватного реагування й ефективного вирішення. Різноманітні способи подолання стресових ситуацій являють собою копінг-поведінку особистості.

Відомо, що на здоров'я й особистісний розвиток підлітка впливають низка біологічних, соціальних, психологічних та економічних чинників, але одним із найважливіших серед них $\epsilon$ взаємини в родині, де виховується підліток, зокрема й особливості батьківської копінг-поведінки [7, c. 61-66]. 
Аналіз останніх досліджень i публікацій. Вивчення особливостей взаємин між батьками і підлітками завжди було в центрі уваги дослідників, оскільки саме характер таких взаємин визначає соціально-психологічний клімат життя дитини та значною мірою впливає на розвиток іiі особистості.

I.C. Кон уважає, що немає жодного соціального чи психологічного аспекту поведінки підлітків, який би не залежав від їхніх сімейних умов [6, c. 16-19].

Взаємозв'язок психологічної атмосфери в сім'ї й особливостей психічного розвитку підлітка досліджували Ю.П. Азаров, О.В. Анопрієнко, Л.В. Виноградова, С.І. Голод, С.Б. Кузікова, В.П. Меньшутін та ін.

Проблеми індивідуально-психологічного розвитку підлітків вивчали такі українські вчені, як: I.С. Булах, І.М. Бушай, Л.В. Долинська, Т.М. Зелінська, Є.М. Калюжна, С.Б. Кузікова, Т.М. Титаренко й інші.

I.C. Булах зазначає, що становлення провідного новоутворення підлітка - почуття дорослості - значною мірою зумовлюється соціальною ситуацією розвитку [2].

О.В. Анопрієнко у працях, присвячених дослідженню впливу стилю батьківської поведінки на виникнення і подолання хронічного стресу в підлітків, вказує на взаємозв'язок між стилем батьківської поведінки та формуванням у підлітків механізмів подолання стресових станів, які забезпечують успішність їхньої соціалізації та збереження психічного й фізичного здоров'я [1].

Закордонні дослідники (А. Білінгз, Р. Лазаpyc, С. Фолкман, Р. Муз, Н. Ендлер, Дж. Паркер, М. Перрез, Л. Перлін, М. Райтчерз) у другій половині XX ст. активно вивчали копінг-поведінку особистості $[15 ; 16 ; 18 ; 20 ; 21 ; 22]$.

У процесі проведення аналізу підходів до вивчення копінг-поведінки особистості варто зазначити, що проблема переживання людиною стресу, а особливо спроби його подолання, $є$ надзвичайно важливим аспектом у розумінні копінгу.

Ранні дослідження розглядали копінг-поведінку особистості як реакцію людини на вимоги, які перевищують ії ресурси, а згодом і як реакцію на щоденні стресові ситуації.

Закордонними і вітчизняними науковцями були розглянуті різноманітні аспекти копінг-поведінки особистості. Найбільш розробленою є концепція Ріхарда Лазаруса, який інтерпретує «копінг» як засоби, психологічні захисти, які виробляє людина від психотравмівних ситуацій, і як поведінку, яка впливає на ситуацію [19].

Сучасні дослідники визначають три основні підходи до розуміння поняття «копінг». Егоорієнтований підхід (К. Меннінгер, Г. Вайлант, Н. Хаан) бере свій початок із психоаналітичної теорії Зигмунда Фрейда, у якому копінг-процес розглядається як специфічний его-механізм, спрямований на продуктивну адаптацію особистості у складних обставинах, до якого людина звертається з метою позбавлення від внутрішньої напруги.

Диспозиційні концепції (А. Біллінгс, Р. Моос) визначають копінг як процес, що зумовлений відносно стійкими особистісними рисами, які й визначають реакцію людини на той чи інший стресовий чинник.

Найбільш поширена когнітивно-феноменологічна концепція Р. Лазаруса і С. Фолкмана, яку відносять до третього напряму. Згідно із цією теорією, копінг являє собою динамічний процес, зумовлений суб'єктивністю переживання ситуації та багатьма іншими чинниками, серед яких i специфіка ситуації, і фаза зіткнення зі стресовим чинником.

Вітчизняні дослідники вивчали проблему копінгу здебільшого в контексті формування копінг-поведінки в різних сферах професійної діяльності: педагогічної (А.В. Сидоренко) [11], фахівців податкової служби (Т.А. Ткачук) [13], фахівців пожежної служби (О.І. Склень) [12], слідчих Національної поліції України (М.М. Дідух) [5], фахівців екстрених служб (В.В. Грандт) [4].

Емпірично досліджували копінг-поведінку студентів як специфічного молодіжного контингенту такі українські науковці, як I.О. Корнієнко, Д.Д. Отич [8], 3.А. Сивогракова [10].

Водночас робіт, які були б присвячені дослідженню виявлення взаємозв'язків батьківських копінг-стратегій з індивідуально-психологічними властивостями особистості підлітків, немає.

Постановка завдання. Метою нашого дослідження $є$ виявлення взаємозв'язків копінг-стратегій батьків з індивідуально-психологічними властивостями особистості підлітків.

Виклад основного матеріалу дослідження. 3 метою виявлення взаємозв'язків копінг-стратегій батьків з індивідуально-психологічними властивостями особистості підлітків нами було проведено констатувальний експеримент, у якому взяли участь 128 батьків та 128 підлітків. Для реалізації експерименту нами було проведено використано низку методик: 
1) з батьками: «Методика виявлення індивідуальних копінг-стратегій» Е. Хейма [3, с. 485], яка дозволяє дослідити 26 ситуативно-специфічних варіантів копінгу і призначена для виявлення когнітивних, емоційних та поведінкових копінг-стратегій, їх оцінки за критерієм ефективності;

2) 3 підлітками: «Опитувальник агресивності Баса - Дарки», «Шкала тривожності» Дж. Тейлора, методика дослідження самооцінки (Дембо - Рубінштейн) [14].

За результатами проведення «Методики виявлення індивідуальних копінг-стратегій» Е. Хейма були отримані наступні дані щодо прояву ознак продуктивності - непродуктивності емоційних, когнітивних та поведінкових копінгстратегій батьків.

Як видно з рис. 1, батьки підлітків у складних ситуаціях, пов'язаних із вихованням, використовують адаптивні копінг-стратегії в емоційній сфері (77\%) частіше, ніж у когнітивній та поведінковій, що може свідчити про їхню емоційну готовність до вирішення наявних проблем і впевненість, що існує вихід із будь-якої ситуації. Проте емоційна готовність батьків до подолання труднощів, пов'язаних із вихованням, поряд із досить низьким ступенем осмисленості проблеми (адаптивні когнітивні копінг-стратегії - 36\%) та не досить сформованою готовністю діяти конструктивно для подолання труднощів (адаптивні поведінкові копінг-стратегії - 44\%) не завжди може забезпечувати ефективність копінг-поведінки батьків у складних ситуаціях, пов'язаних із вихованням підлітків.

За нашим припущенням, однією 3 найважливіших індивідуально-психологічних властивос- тей особистості підлітків, на яку може вплинути копінг-поведінка батьків, є самооцінка.

Виходячи із теоретичних положень, представлених у нашому дослідженні, поведінка батьків має значний вплив на розвиток особистості підлітка, зокрема й копінг-поведінка. Для підтвердження даного припущення нами було проведено порівняльне дослідження 3 метою виявлення взаємозв'язку між ефективністю обраних батьками копінг-стратегій та особливостями самооцінки підлітків, результати якого представлені в таблиці 1.

Отже, як бачимо з результатів, представлених у таблиці 1 , батьки підлітків, які мають адекватну самооцінку, здебільшого використовують для подолання складних ситуацій, пов'язаних із вихованням, адаптивні поведінкові (75\%), когнітивні (70\%) та емоційні (49\%) копінг-стратегії за х2-критерієм на 0,01 рівні значущості.

У сім'ях, де батьки використовують неадаптивні поведінкові $(81 \%)$, когнітивні $(80 \%)$ і емоційні (61\%) копінг-стратегії, самооцінка підлітків перебуває на низькому рівні за х2-критерієм на 0,01 рівні значущості.

Простежується взаємозв'язок між використанням батьками відносно адаптивних когнітивних, емоційних та поведінкових і завищеною та низькою самооцінкою підлітків.

У результаті дослідження взаємозв'язку між батьківською копінг-поведінкою та рівнем агресії в підлітків ми отримали результати, які кількісно представлені в таблиці 2.

Як видно з таблиці 2, у сім'ях, де батьки використовують адаптивні когнітивні (48\%), емоційні (48\%), поведінкові (50\%) копінг-стратегії, під-

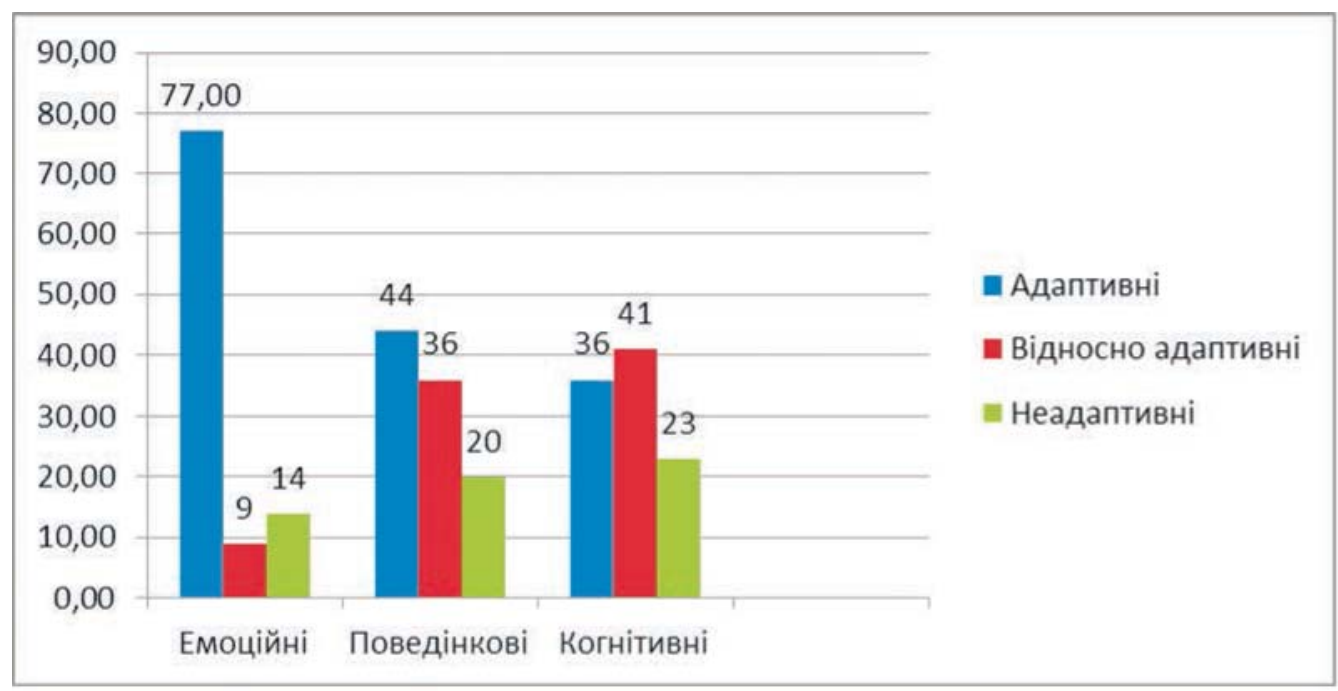

Рис. 1. Кількісні показники ознак продуктивності - непродуктивності копінгстратегій батьків (у \%) 
літки проявляють здебільшого низький рівень агресії за х2-критерієм на 0,01 рівні значущості.

А в тих родинах, де батьки під час подолання труднощів проявляють неадаптивні когнітивні (70\%), емоційні (72\%), поведінкові (85\%) копінгстратегії, підлітки мають високий рівень агресії за х2-критерієм на 0,01 рівні значущості.

Використання батьками відносно адаптивних когнітивних копінг-стратегій пов'язане із середнім рівнем прояву агресії в підлітків (65\%), емоційних - з високим рівнем агресії (58\%), поведінкових - із середнім (52\%) рівнем агресії у підлітків за х2-критерієм на 0,01 рівні значущості.
Одним із завдань нашого дослідження було виявлення взаємозв'язків між батьківськими копінг-стратегіями та рівнем тривожності в підлітків.

А.М. Прихожан вказує, що тривожність $є$ переживанням емоційного дискомфорту, яке пов'язане 3 очікуванням неблагополуччя, 3 передчуттям небезпеки [9, с. 39].

Результати емпіричного дослідження батьківських копінг-стратегій та рівня тривожності у підлітків представлені в таблиці 3.

У результаті проведеного аналізу кількісних показників дослідження взаємозв'язку батьків-

Кількісні показники взаємозв'язків копінг-стратегій батьків

Таблиця 1 і особливостей самооцінки підлітків

\begin{tabular}{|c|c|c|c|c|c|c|c|}
\hline \multirow{3}{*}{ Копінг-стратегії } & \multirow{3}{*}{$\begin{array}{l}\text { Ознака продуктивності } \\
\text { - непродуктивності }\end{array}$} & \multicolumn{6}{|c|}{ Особливості самооцінки підлітків } \\
\hline & & \multicolumn{2}{|l|}{ Адекватна } & \multicolumn{2}{|l|}{ Завищена } & \multicolumn{2}{|l|}{ Низька } \\
\hline & & $\begin{array}{l}\text { А б с о л ю т н а } \\
\text { кількість }\end{array}$ & $\%$ & $\begin{array}{l}\text { А б с о л ю т н а } \\
\text { кількість }\end{array}$ & $\%$ & $\begin{array}{l}\text { А б с о л ю т н а } \\
\text { кількість }\end{array}$ & $\%$ \\
\hline \multirow{3}{*}{ Когнітивні } & Адаптивні (46 осіб) & 32 & 70 & 8 & 17 & 6 & 13 \\
\hline & $\begin{array}{l}\text { Відносно адаптивні (52 } \\
\text { особи) }\end{array}$ & 23 & 44 & 18 & 35 & 11 & 21 \\
\hline & Неадаптивні (30 осіб) & - & - & 6 & 20 & 24 & 80 \\
\hline \multirow{3}{*}{ Емоційні } & Адаптивні (98 осіб) & 48 & 49 & 32 & 33 & 18 & 18 \\
\hline & $\begin{array}{l}\text { Відносно адаптивні (12 } \\
\text { осіб) }\end{array}$ & - & - & 8 & 67 & 4 & 33 \\
\hline & Неадаптивні (18 осіб) & 2 & 11 & 5 & 28 & 11 & 61 \\
\hline \multirow{3}{*}{ Поведінкові } & Адаптивні (56 осіб) & 42 & 75 & 14 & 25 & - & - \\
\hline & $\begin{array}{l}\text { Відносно адаптивні (46 } \\
\text { особи) }\end{array}$ & 7 & 15 & 9 & 20 & 30 & 65 \\
\hline & Неадаптивні (26 осіб) & 1 & 4 & 4 & 15 & 21 & 81 \\
\hline
\end{tabular}

Таблиця 2

Кількісні показники взаємозв'язків копінг-стратегій батьків та рівнів прояву агресії в підлітків

\begin{tabular}{|c|c|c|c|c|c|c|c|}
\hline \multirow[b]{3}{*}{ Копінг-стратегії } & \multirow{3}{*}{$\begin{array}{c}\text { Ознака продуктивності } \\
\text { - непродуктивності }\end{array}$} & \multicolumn{6}{|c|}{ Рівень прояву агресії } \\
\hline & & \multicolumn{2}{|c|}{ Високий рівень } & \multicolumn{2}{|c|}{ Середній рівень } & \multicolumn{2}{|c|}{ Низький рівень } \\
\hline & & $\begin{array}{c}\text { Абсолютна } \\
\text { кількість }\end{array}$ & $\%$ & $\begin{array}{l}\text { Абсолютна } \\
\text { кількість }\end{array}$ & $\%$ & $\begin{array}{l}\text { Абсолютна } \\
\text { кількість }\end{array}$ & $\%$ \\
\hline \multirow{3}{*}{ Когнітивні } & Адаптивні (46 осіб) & 7 & 15 & 17 & 37 & 22 & 48 \\
\hline & $\begin{array}{c}\text { Відносно адаптивні } \\
\text { (52 особи) }\end{array}$ & 15 & 29 & 34 & 65 & 3 & 6 \\
\hline & Неадаптивні (30 осіб) & 21 & 70 & 9 & 30 & - & - \\
\hline \multirow{3}{*}{ Емоційні } & Адаптивні (98 осіб) & 13 & 13 & 38 & 39 & 47 & 48 \\
\hline & $\begin{array}{c}\text { Відносно адаптивні } \\
(12 \text { осіб) }\end{array}$ & 7 & 58 & 3 & 25 & 2 & 17 \\
\hline & Неадаптивні (18 осіб) & 13 & 72 & 4 & 22 & 1 & 6 \\
\hline \multirow{3}{*}{ Поведінкові } & Адаптивні (56 осіб) & 8 & 14 & 20 & 36 & 28 & 50 \\
\hline & $\begin{array}{c}\text { Відносно адаптивні } \\
(46 \text { особи) }\end{array}$ & 13 & 28 & 24 & 52 & 9 & 20 \\
\hline & Неадаптивні (26 осіб) & 22 & 85 & 4 & 15 & - & - \\
\hline
\end{tabular}


Таблиця 3

Кількісні показники взаємозв'язків копінг-стратегій батьків та рівнів тривожності в підлітків

\begin{tabular}{|c|c|c|c|c|c|c|c|}
\hline \multirow[b]{3}{*}{ Копінг-стратегії } & \multirow{3}{*}{$\begin{array}{c}\text { Ознака продуктивності } \\
\text { - непродуктивності }\end{array}$} & \multicolumn{6}{|c|}{ Рівень тривожності } \\
\hline & & \multicolumn{2}{|c|}{ Високий рівень } & \multicolumn{2}{|c|}{ Середній рівень } & \multicolumn{2}{|c|}{ Низький рівень } \\
\hline & & $\begin{array}{l}\text { Абсолютна } \\
\text { кількість }\end{array}$ & $\%$ & $\begin{array}{c}\text { Абсолютна } \\
\text { кількість }\end{array}$ & $\%$ & $\begin{array}{l}\text { Абсолютна } \\
\text { кількість }\end{array}$ & $\%$ \\
\hline \multirow{3}{*}{ Когнітивні } & Адаптивні (46 осіб) & 3 & 7 & 18 & 39 & 25 & 54 \\
\hline & $\begin{array}{c}\text { Відносно адаптивні (52 } \\
\text { особи) }\end{array}$ & 15 & 29 & 28 & 54 & 9 & 17 \\
\hline & Неадаптивні (30 осіб) & 18 & 60 & 7 & 23 & 5 & 17 \\
\hline \multirow{3}{*}{ Емоційні } & Адаптивні (98 осіб) & 6 & 6 & 23 & 24 & 69 & 70 \\
\hline & $\begin{array}{c}\text { Відносно адаптивні (12 } \\
\text { осіб) }\end{array}$ & 5 & 42 & 6 & 50 & 1 & 8 \\
\hline & Неадаптивні (18 осіб) & 11 & 61 & 7 & 39 & - & - \\
\hline \multirow{3}{*}{ Поведінкові } & Адаптивні (56 осіб) & 7 & 13 & 32 & 57 & 17 & 30 \\
\hline & $\begin{array}{c}\text { Відносно адаптивні (46 } \\
\text { особи) }\end{array}$ & 4 & 9 & 34 & 74 & 8 & 17 \\
\hline & Неадаптивні (26 осіб) & 19 & 73 & 5 & 19 & 2 & 8 \\
\hline
\end{tabular}

ських копінг-стратегій та рівня тривожності підлітків можна зробити такі висновки: підлітки, чиї батьки використовують адаптивні когнітивні (54\%), емоційні (70\%) копінг-стратегії, мають здебільшого низький рівень тривожності за х2-критерієм на 0,01 рівні значущості. Використання батьками адаптивних поведінкових копінг-стратегій більшою мірою $\epsilon$ взаємопов'язаним із середнім рівнем прояву тривожності в підлітків (57\%) за х2-критерієм на 0,01 рівні значущості.

Високий рівень тривожності в підлітків значною мірою є взаємопов'язаним із використанням їхніми батьками неадаптивних когнітивних (60\%), емоційних (61\%) та поведінкових (73\%) копінг-стратегій за х2-критерієм на 0,01 рівні значущості.
Використання батьками відносно адаптивних копінг-стратегій більшою мірою пов'язане iз середнім рівнем тривожності в підлітків за х2-критерієм на 0,01 рівні значущості.

Висновки. Результати емпіричного дослідження батьківської копінг-поведінки й індивідуальнопсихологічних властивостей особистості підлітків засвідчують, що використання батьками ефективних когнітивних, емоційних та поведінкових копінгстратегій у подоланні складних ситуацій, пов'язаних iз вихованням, впливає на такі індивідуально-психологічні властивості особистості підлітків, як низькі показники агресивності, адекватна самооцінка та низька тривожність, сприяє гармонійному розвитку особистості підлітка, а формування ефективних копінг-стратегій батьків стане пріоритетним завданням наших подальших досліджень.

\section{Список літератури:}

1. Анопрієнко О.В. Стиль батьківської поведінки як чинник виникнення і подолання хронічного стресу в підлітковому віці : автореф. дис. ... канд. психол. наук: 19.00.07. Київ, 2017. 21 с.

2. Булах І.С. Психологічні основи особистісного зростання підлітків : автореф. дис. ... докт. психол. наук: 19.00.07. Київ, 2004. 42 с.

3. Вассерман Л.И. Медицинская психодиагностика. Теория, практика и обучение / Л.И. Вассерман, О.Ю. Щелкова. Санкт-Петербург ; Москва : Изд. центр «Академия», 2004. 736 с.

4. Грандт В.В. Копінг-ресурси як чинник збереження професійного здоров'я особистості : автореф. дис. ... канд. психол. наук: 19.00.01. Київ, 2012. 20 с.

5. Дідух М.М. Конструктивна копінг-поведінка слідчих Національної поліції України у психологічно напружених ситуаціях : дис. ... канд. психол. наук: 19.00.06. Київ, 2018. 227 с.

6. Кон И.С. Родители и дети. Психология ранней юности. Москва : Просвещение, 1989. С. 16-19.

7. Кошонько Г.А. Особливості емоційних взаємин батьків та дітей-підлітків. Деструктивні емоиійні стани учнів: генеза, психологічні механізми, профілактика та корекиія : матеріали Всеукраїнської науково-практичної конференції, 20 листопада 2012 р. Вінниця : ВОІПОПП, 2012. С. 61-66. 
8. Отич Д.Д. Я-концепція як чинник копінг-стратегій майбутніх психологів : дис. . . . канд. психол. наук: 19.00.07. Київ, 2014. 388 с.

9. Прихожан А.М. Тревожность у детей и подростков: психологическая природа и возрастная динамика. Москва : МОДЭК, 2000. 304 с.

10. Сивогракова 3.А. Психологічні особливості подолання студентами складних життєвих ситуацій : автореф. дис. ... канд. психол. наук: 19.00.07. Київ, 2010. 20 с.

11. Сидоренко А.В. Психологічні особливості копінг-поведінки вчителів у педагогічній взаємодії з підлітками-девіантами : автореф. дис. ... канд. психол. наук: 19.00.07. Київ, 2012. 20 с.

12. Склень О.І. Психологічні особливості поведінкових стратегій подолання стресу в професійній діяльності працівників пожежно-рятувальних підрозділів МНС України : дис. ... канд. психол. наук: 19.00.09. Харків, 2008. 220 с.

13. Ткачук Т.А. Психологія копінг-поведінки особистості майбутнього і діючого податківця : автореф. дис. ... докт. психол. наук: 19.00.07. Київ, 2013. 41 с.

14. Учебное пособие / под ред. Д.Я. Райгородского. Самара : Бахрах-М, 2001. 672 с.

15. Folkman S. Personal control and stress and coping processes: A theoretical analysis. Journal of Personality and Social Psychology. 1984. Vol. 46.

16. Endler N.S, Parker J.D.A. Coping Inventory for Stressful Situations. (CISS) : Manual. Toronto : Multi Health System, 1990.

17. Lazarus R.S. Psychological stress and the coping process. New York : McGraw Hill, 1966. 29 p.

18. Lazarus R.S. The stress and coping paradigm. Distorter et al. Models for Clinical Psychopathology. New York, 1981. P. 177-214.

19. Lazarus R.S. Fifty years of research and theory of R.S. Lazarus (An analyses of historical and perennial issues). New York, 1998.

20. Moos R.H., Billings A.G. Conceptualizing and measuring coping resources and processes. Handbook of Stress / L. Goldenberg, S. Breznitz (Eds.) New York, 1982. P. 212-230.

21. Pearling L., Schooler C., Health J. The structure of coping. Journal of Health and Social Behavior. 1978. Vol. 19. P. 2-21.

22. Perrez M., Reicherts M. Stress, Coping and Health: a situation behavior approach : theory, methods, applications ; Foreword by R.S. Lazarus. Seattle ; Toronto ; Bern : Hogret and Huber Publishers, 1992. 233 p.

\section{Chernyakova H.A. THE INTERCONNECTION BETWEEN PARENTAL COPING STRATEGIES AND INDIVIDUAL PSYCHOLOGICAL PROPERTIES OF TEENAGERS}

The article reveals the concept of "coping behavior" of the individual as a cognitive, emotional and behavioral effort to overcome stressful situations. The problem of the interconnection between parental coping strategies and individual psychological properties of teenagers is considered. A brief analysis of the results of a study of individual ways of parents to overcome stressful situations related to education and such individual psychological characteristics of adolescents as: the level of anxiety, self-esteem and aggression. Emphasis is placed on the significant impact of the supportive environment of the family on the development of the adolescent's personality in times of crisis, both individual development and society as a whole.

An analysis of recent foreign and fatherland researchs and publications on the problem of coping behavior of the individual in stressful situations, as well as the problem of parent-child relationships during the adolescent crisis. The main approaches to the study of the problem of coping are considered: ego-oriented, dispositional, dynamic. The concept of coping strategies is revealed, their classification is presented.

It has been established that parents' use of effective cognitive, emotional and behavioral coping strategies in overcoming difficult situations related to upbringing affects such individual psychological personality traits of adolescents as indicators of aggression, self-esteem and anxiety, towards their optimization. In families where parents have maladaptive coping strategies, adolescents have high levels of aggression, low or high (inadequate) self-esteem, and high levels of anxiety.

Effective coping behavior of parents contributes to the harmonious development of the adolescent's personality. Formation of effective parental coping strategies is a priority for practical and theoretical research in the field of modern psychological science.

Key words: coping behavior, cognitive, emotional, behavioral coping strategies, coping effectiveness, stress, anxiety, aggression, self-esteem, adolescence. 